\title{
Antioxidant and inhibition of senescence effects of embelin
}

Jin Jung Ahn ${ }^{1}$ and Hee Jung Yong ${ }^{2^{*}}$

\begin{abstract}
Background: Embelin is a major active ingredient of Embelia ribes Burm. belonging to Myrsinaceae, an important traditional medicinal plant of Indian origin. Embelin has a benzoquinone derivative structure and has been studied for anticancer, anti-inflammatory, and antioxidative effects. However, there have been no studies on the use of cosmetic raw materials for embelin. In this study, antioxidant and inhibition of senescence effects of embelin were examined using hydrogen peroxide $\left(\mathrm{H}_{2} \mathrm{O}_{2}\right)$-induced cellular aging model of human dermal fibroblast.

Methods: Cell viability was measured using the principle of water-soluble tetrazolium salt (WST-1) assay. qRT-PCR was used to quantitatively analyze gene expression patterns in human dermal fibroblasts (HDFs) by embelin. Dichlorofluorescein diacetate (DCF-DA) was used to measure changes in intracellular reactive oxygen species (ROS) concentration. Cell senescence was measured using the senescence-associated $\beta$-galactosidase (SA- $\beta$-galactosidase) assay, a method of staining $\beta$-galactosidase. A wound healing assay was used to observe cell mobility.

Results: The WST-1 assay demonstrated that decreased cell viability by $\mathrm{H}_{2} \mathrm{O}_{2}$ was restored by embelin in a dose-dependent manner. In addition, the expression of SOD1, GPX1, and CAT genes were upregulated by embelin suggesting that embelin-induced antioxidant capability may be enhanced through the upregulation of intracellular antioxidant-related genes. To determine whether embelin inhibits cell senescence in $\mathrm{H}_{2} \mathrm{O}_{2}$-induced senescence model of HDFs, the SA- $\beta$-galactosidase assay was performed. Embelin decreased the SA- $\beta$-galactosidase activity in a dose-dependent manner in $\mathrm{H}_{2} \mathrm{O}_{2}$-treated HDFs. Moreover, the expression of p21 and MMP1 genes were reduced by embelin in $\mathrm{H}_{2} \mathrm{O}_{2}$-treated $\mathrm{HDFs}$ in a dose-dependent manner. However, $\mathrm{COL} 1 \mathrm{~A} 1$ genes were increased by embelin in $\mathrm{H}_{2} \mathrm{O}_{2}$-treated $\mathrm{HDFs}$ in a dose-dependent manner.
\end{abstract}

Conclusions: These results suggest that embelin has a potential as an antiaging cosmetic ingredient with antioxidant and anti-senescence properties.

Keywords: Embelin, Antioxidative, Anti-senescence, Fibroblast, Hydrogen peroxide

\section{Background}

The skin consists of the epidermis, dermis, and subcutaneous tissue. The dermis, which occupies the majority of the skin, consists of cells and extracellular matrix (ECM). The ECM comprises fibrous proteins and substrates, such as collagenous fibers and elastic fibers (Braverman and Fonferko 1982). In the dermis, fibroblasts are the most representative constituent cells, which produce collagen, elastin, and substrate that controls wrinkles, elasticity, and water retention.

\footnotetext{
*Correspondence: yong28@hanmail.net

${ }^{2}$ Beauty People Beauty School, 68, Dolma-ro, Bundang-gu, Seongnam-si, Gyeonggi-do, Republic of Korea

Full list of author information is available at the end of the article
}

Dysfunction of fibroblasts in the dermis promotes the expression of various proteases, thereby promoting collagen and elastin degradation. As a result, the dermis contracts to form wrinkles, and elasticity and moisture decrease, resulting in skin aging (El-Domyati et al. 2002; Matsumura and Ananthaswamy 2004; Kang et al. 2005).

Such skin aging is divided into endogenous aging and extrinsic aging due to changes in skin structure and function caused by the passing of time or environmental factors (Uitto 1986; Campisi 1998). Endogenous aging is caused by the depletion of skin cells gradually with aging, which is mainly caused by reactive oxygen species (ROS) generated during cellular metabolism in skin cells; 
exogenous aging is caused by external environmental factors (Yoon et al. 2013).

ROS, which is the main cause of endogenous aging, has a higher reactivity than $\mathrm{O}_{2}$ in the general molecular state and includes $\mathrm{O}_{2}^{-}$(superoxide anion), $\mathrm{H} 2 \mathrm{O} 2$ (hydrogen peroxide), and $\mathrm{OH}^{-}$(hydroxyl radical) (Thannickal and Fanburg 2000). These ROS are constantly produced by normal intracellular activity, and most of them are removed by antioxidant enzymes, such as superoxide dismutase (SOD), glutathione peroxidase (GPx), and catalase (CAT) (Urso and Clarkson 2003). The body's antioxidant enzyme, SOD, converts $\mathrm{O}_{2}^{-}$to $\mathrm{H}_{2} \mathrm{O}_{2}$ and $\mathrm{O}_{2}$, and the $\mathrm{H}_{2} \mathrm{O}_{2}$ produced in this process is eliminated by GPx and CAT (Heck et al. 2003).

DNA damage caused by oxidative stress activates p53, a transcription factor that determines cell repair or apoptosis (Miliani de Marval and Zhang 2011), and expresses the senescence-promoting gene p21 (Smits and Medema 2001). p21 inhibits cyclin D/cyclin-dependent kinase 4 (CDK4) and cyclin E/cyclin-dependent kinase 2 (CDK2), thereby inhibiting cell growth (Stein and Dulic 1995).

A total of $90 \%$ of the dermis is occupied by collagen, contributing to the firmness and elasticity of the skin (Philips et al. 2011). ROS stimulate collagen degradation in the dermis by activating nuclear factor $\mathrm{\kappa B}(\mathrm{NF}-\mathrm{kB})$ and increasing the expression of matrix metallopeptidase 1 (MMP1) (Yoon et al. 2013) and collagen type I alpha 1 chain (COL1A1). Inhibition of this expression leads to skin elasticity and wrinkles, resulting in skin aging (Varani et al. 2002; Lee et al. 2012).

Embelin is a major active ingredient in Embelia ribes Burm. (Myrsinaceae), an important traditional medicinal plant in India. It has a benzoquinone derivative structure and a wide range of biological activities, such as antioxidation, anticancer, anti-inflammatory, analgesic, insect repellent, and antimicrobial effects (Radhakrishana and Gnanamani 2014). Research on embelin has focused on its effects against various cancers, such as pancreatic cancer and breast cancer (Mori et al. 2007; Li et al. 2013), its anti-inflammatory effects in arthritis (Dharmapatni et al. 2015), and its antioxidant effects in liver damage and diabetes (Singh et al. 2009; Naik et al. 2013). Other studies on its neuroprotective effects in brain cells have also been reported (Dhadde et al. 2016).

Research on the development of cosmetic materials for antiaging has been increasing worldwide, and anticancer, anti-inflammation, and antioxidant studies on embelin in the field of medicine have been reported, but to the best of our knowledge, research on embelin as a cosmetic raw material has not been conducted. Therefore, we investigated the antioxidative and senescenceinhibiting effects of embelin in $\mathrm{H}_{2} \mathrm{O}_{2}$-induced human dermal fibroblasts, as well as the applicability of embelin as an antiaging component of cosmetics.

\section{Methods}

\section{Cell culture}

In this study, human dermal fibroblasts (HDFs) (ATCC, USA) were used. Cell culture was performed with $10 \%$ fetal bovine serum (FBS) and 1\% penicillin/streptomycin (penicillin $100 \mathrm{IU} / \mathrm{mL}$, streptomycin $100 \mu \mathrm{g} / \mathrm{mL}$; Invitrogen, USA) in DMEM (Dulbecco's modified Eagle's medium), and the cells were cultured under conditions of $5 \% \mathrm{CO}_{2}$ and $37^{\circ} \mathrm{C}$.

\section{Sample treatment}

Embelin (Sigma-Aldrich, USA) was purchased in pure purified (> 98\%) powder form and dissolved in dimethyl sulfoxide (DMSO; Sigma-Aldrich) at the appropriate concentration for use in the experiment. HDFs were cultured in a cell culture dish for $24 \mathrm{~h}$. Embelin was added to the culture medium for $24 \mathrm{~h}$, after which $\mathrm{H}_{2} \mathrm{O}_{2}$ was applied at a constant concentration for $3 \mathrm{~h}$, followed by analysis.

\section{Cell viability estimation}

Cell viability was measured using the water-soluble tetrazolium salt (WST-1) assay. A total of $100 \mu \mathrm{L}$ of HDFs $\left(3 \times 10^{3}\right.$ cells/well $)$ were inoculated on a 96-well plate and incubated for $24 \mathrm{~h}$. Then, embelin was applied at concentrations of $2.5,5,7.5$, and $10 \mu \mathrm{M}$ for $24 \mathrm{~h}$. After incubation for $1 \mathrm{~h}$, the absorbance was measured at $490 \mathrm{~nm}$ using a microplate reader (Bio-Rad, USA). This was repeated three times to derive the mean and standard deviation of cell viability.

\section{qRT-PCR analysis}

Quantitative real-time PCR (qRT-PCR) was performed for quantitative analysis of gene expression patterns in HDFs upon exposure to embelin. I mixed $0.2 \mu \mathrm{M}$ primers, $50 \mathrm{mM} \mathrm{KCl}, 20 \mathrm{mM}$ Tris $/ \mathrm{HCl} \mathrm{pH} \mathrm{8.4,} 0.8 \mathrm{mM}$ dNTP, $0.5 \mathrm{U}$ Extaq DNA polymerase, $3 \mathrm{mM} \mathrm{MgCl}_{2}$, and $1 \times$ SYBR Green (Invitrogen) in PCR tube to manufacture reaction solution and used Linegene $\mathrm{K}$ (BioER, China). After denaturation with temperature at $94{ }^{\circ} \mathrm{C}$ for $30 \mathrm{~min}$, I performed denaturation at $94{ }^{\circ} \mathrm{C}$ for $30 \mathrm{~s}$, annealing at $58{ }^{\circ} \mathrm{C}$ for $30 \mathrm{~s}$, and polymerization at $72{ }^{\circ} \mathrm{C}$ for $30 \mathrm{~s}$ for 40 cycles and proceeded PCR. I verified the effectiveness of PCR with melting curve, and by standardizing the expression of $\beta$-actin, I performed the comparative analysis for each gene expression. The primer used in experiment is shown in Table 1.

\section{Cell senescence measurement}

Cell senescence was measured by the senescenceassociated $\beta$-galactosidase (SA- $\beta$-galactosidase) assay. The senescence detection kit (Biovision, USA) was used, which produced blue staining by degrading X-gal by $\beta$-galactosidase activation only in aged cells. Cells 
Table 1 List of primers used in this study

\begin{tabular}{lll}
\hline Gene & Forward primer & Reverse primer \\
\hline$\beta$-actin & GGATTCCTATGTGGGCGACGA & CGCTCGGTGAGGATCTTCATG \\
SOD1 & GGGAGATGGCCCAACTACTG & CCAGTTGACATGCAACCGTT \\
GPX1 & TTCCCGTGCAACCAGTTTG & GGACGTACTTGAGGGAATTCAGA \\
CAT & ATGGTCCATGCTCTCAAACC & CAGGTCATCCAATAGGAAGG \\
p21 & GTCCAGCGACCTTCCTCATCCA & CCATAGCCTCTACTGCCACCATC \\
MMP1 & TCTGACGTTGATCCAGAGAGCAG & CAGGGTGACACCAGTGACTGCAC \\
COLIA1 & AGGGCCAAGACGAAGACATC & AGATCACGTCATCGCACAACA \\
\hline
\end{tabular}

were inoculated on a $60-\mathrm{mm}$ culture dish at $2 \times 10^{5}$ cells/well and cultured for $24 \mathrm{~h}$. Then, the cells were treated with the sample and the stimulus appropriately and further cultured. The medium was removed from the cultured cells and washed with $1 \mathrm{~mL}$ of PBS, and $0.5 \mathrm{~mL}$ of fixing solution was added thereto, followed by immobilization at room temperature for $15 \mathrm{~min}$. A total of $0.5 \mathrm{~mL}$ of a staining solution $(470 \mu \mathrm{L}$ of staining solution, $5 \mu \mathrm{L}$ of staining supplement, $20 \mu \mathrm{L}$ of $20 \mathrm{mg} /$ $\mathrm{mL} \mathrm{X}$-gal in dimethylformamide) was added to the immobilized cells, and the cells were stained by incubation at $37{ }^{\circ} \mathrm{C}$ for $24 \mathrm{~h}$. The stained cells were then washed with PBS, the number of stained cells was measured using an optical microscope (Olympus, Japan), and the ratio of cells was analyzed.

\section{ROS measurement}

Dichlorofluorescein diacetate (DCF-DA) was used to measure changes in intracellular ROS concentration. DCF-DA is oxidized by ROS in the presence of peroxides associated with hydrogen peroxide, resulting in green fluorescence (Karlsson et al. 2010). Cells were inoculated in a $60-\mathrm{mm}$ culture dish at $2 \times 10^{5}$ cells/well, cultured for $24 \mathrm{~h}$, treated with embelin, and cultured further. For harvesting of cells, $10 \mu \mathrm{M}$ DCF-DA, a staining reagent for measuring ROS, was added and incubated for $30 \mathrm{~min}$. After the addition of PBS, the cells were released and analyzed by flow cytometry (BD Biosciences) to measure ROS change. $N$-Acetyl-L-cysteine (NAC; Calbiochem, USA), which has ROS scavenger function as a positive control, was also measured in the same manner to compare the efficacy of ROS removal.

\section{Wound-healing assay}

A wound-healing assay was used to observe the change of cell migration distance. This technique allows the movement of cells and their filling of a damaged area to be visualized. Cells were seeded on a six-well plate and cultured until reaching $90 \%$ confluence. After $24 \mathrm{~h}$, the medium was changed to low-serum medium. A marker line was introduced on the bottom of the cell culture dish, and three scratched lines were created using the tip of a $200-\mu \mathrm{L}$ pipette. After $24 \mathrm{~h}$, phase contrast $\times 10$ photographs were taken using an optical microscope (Olympus, Japan), and images were analyzed.

\section{Statistical processing}

All experiments in this study were performed in triplicate independently under the same conditions, and the results are expressed as mean \pm standard deviation. The test results were analyzed by Student's $t$ test, and statistical significance $\left({ }^{*} p<0.05, * * p<0.01,{ }^{* * * *} p<0.001\right)$ was considered when the $p$ value was $0.05,0.01$, or 0.001 or less.

\section{Results \\ Cell viability analysis}

The viability of HDFs was measured after human dermal fibroblast cell treatment with $2.5,5,7.5$, and $10 \mu \mathrm{M}$ embelin for $24 \mathrm{~h}$. The results showed that cell viability was $97 \%$ at $2.5 \mu \mathrm{M}, 93 \%$ at $5 \mu \mathrm{M}$, and $86 \%$ at $7.5 \mu \mathrm{M}$, depending on the concentration of embelin. However, cell viability was reduced to $67 \%$ at $10 \mu \mathrm{M}$ and was considered to be cytotoxic. Therefore, $7.5 \mu \mathrm{M}$ was used at the maximum concentration (Fig. 1a).

To investigate the cytoprotective effect of embelin against damage to human dermal fibroblast cells by $\mathrm{H}_{2} \mathrm{O}_{2}$, embelin was pretreated for $24 \mathrm{~h}$ at 2.5, 5, and $7.5 \mu \mathrm{M}$, followed by treatment with $750 \mu \mathrm{M} \mathrm{H}_{2} \mathrm{O}_{2}$ for $3 \mathrm{~h}$. Experimentally, at higher concentrations of hydrogen peroxide, more than half of the cell deaths were observed, making it difficult to confirm the effect on embelin. Cell viability was reduced to $74 \%$ with $750 \mu \mathrm{M} \mathrm{H}_{2} \mathrm{O}_{2}$ without embelin treatment in HDFs. Cell viability was also reduced by embelin to 83,86 , and $91 \%$ upon pretreatment with $2.5,5$, and $7.5 \mu \mathrm{M}$ embelin (Fig. 1b).

\section{Antioxidant effect of embelin}

The effect of embelin on SOD1, a representative antioxidant enzyme, was confirmed by qRT-PCR. The results showed that $S O D 1$ gene expression decreased from 1 to 0.53 by $750 \mu \mathrm{M} \mathrm{H} \mathrm{H}_{2} \mathrm{O}_{2}$, but SOD1 gene expression increased to $0.74,0.88$, and 0.97 after treatment with $750 \mu \mathrm{M} \mathrm{H} \mathrm{H}_{2} \mathrm{O}_{2}$ after $2.5,5$, and $7.5 \mu \mathrm{M}$ embelin pretreatment (Fig. 2a). 


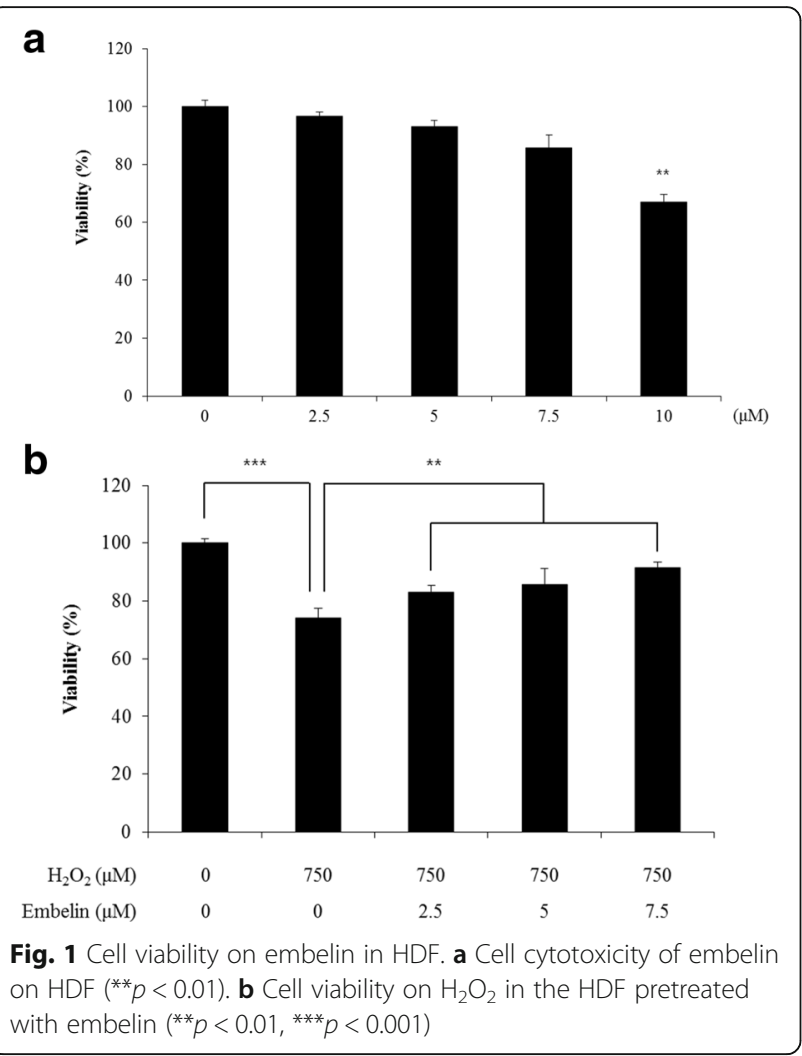

The effect of embelin on the expression of the antioxidant enzyme encoded by the GPx1 gene was confirmed by qRT-PCR. The results showed that GPx1 gene expression was decreased from 1 to 0.73 by $750 \mu \mathrm{M} \mathrm{H}_{2} \mathrm{O}_{2}$, but GPx1 gene expression was increased to 1.04, 1.16, and 1.31 upon treatment with $750 \mu \mathrm{M} \mathrm{H}_{2} \mathrm{O}_{2}$ after 2.5, 5, and $7.5 \mu \mathrm{M}$ embelin pretreatment, respectively (Fig. 2b).

The effect of embelin on the expression of the antioxidant enzyme encoded by the $C A T$ gene was confirmed by qRT-PCR. The results showed that $C A T$ gene expression was decreased from 1 to 0.72 by $750 \mu \mathrm{M} \mathrm{H}_{2} \mathrm{O}_{2}$, but it increased to $0.88,1.15$, and 1.43 upon treatment with $750 \mu \mathrm{M} \mathrm{H}_{2} \mathrm{O}_{2}$ after pretreatment with embelin at 2.5, 5, and $7.5 \mu \mathrm{M}$, respectively (Fig. 2c).

DCF-DA was used to confirm that ROS in HDFs produced by $\mathrm{H}_{2} \mathrm{O}_{2}$ were removed by embelin. DCF-DA is deacetylated in cells and reacts with ROS to convert to DCF, a fluorescent substance. The fluorescence values of the DCF thus formed were measured using flow cytometry (BD Biosciences, USA). NAC, also known as a ROS scavenger, was compared with a positive control. The results showed that ROS production was increased from 1 to 4.05 upon treatment with $750 \mu \mathrm{M} \mathrm{H} \mathrm{H}_{2} \mathrm{O}_{2}$ but decreased to 2.81 and 1.19 upon treatment with $750 \mu \mathrm{M}$ $\mathrm{H}_{2} \mathrm{O}_{2}$ after pretreatment with embelin at 2.5 and $7.5 \mu \mathrm{M}$. In the case of the positive control group NAC, ROS production was reduced to 1.12 upon treatment with $750 \mu \mathrm{M} \mathrm{H}_{2} \mathrm{O}_{2}$ after $10 \mathrm{mM}$ pretreatment (Fig. 2d). In particular, at low concentrations of embelin, the levels of NAC were similar to those of the positive control, suggesting that the ROS removal effect was superior.

\section{Inhibition of senescence effect of embelin}

The senescence-associated $\beta$-galactosidase (SA- $\beta$-galactosidase) assay was used to determine the effect of embelin on $\mathrm{H}_{2} \mathrm{O}_{2}$-induced HDFs. The aging of cells increased the activity of SA- $\beta$-galactosidase at $\mathrm{pH}$ 6.0. The results showed that cell senescence was increased from 14 to $84 \%$ by $750 \mu \mathrm{M} \mathrm{H}_{2} \mathrm{O}_{2}$, but after pretreatment with embelin at 2.5, 5, and $7.5 \mu \mathrm{M}$, treatment with $750 \mu \mathrm{M} \mathrm{H}_{2} \mathrm{O}_{2}$ was associated with reductions of cell viability by 60,39 , and $29 \%$, respectively (Fig. 3a).

The expression of $p 21$ by embelin was confirmed by qRT-PCR. Specifically, the expression of the $p 21$ gene was increased from 1 to 9.86 by $750 \mu \mathrm{M} \mathrm{H}_{2} \mathrm{O}_{2}$ but was decreased to $7.50,3.24$, and 1.88 upon treatment with $750 \mu \mathrm{M} \mathrm{H}_{2} \mathrm{O}_{2}$ after pretreatment with 2.5 , 5, and $7.5 \mu \mathrm{M}$ embelin (Fig. 3b).

The expression of the $M M P 1$ gene, which degrades most of the dermis, type I collagen, was determined by qRT-PCR. The results showed that expression of the $M M P 1$ gene was increased from 1 to 4.48 by $750 \mu \mathrm{M}$ $\mathrm{H}_{2} \mathrm{O}_{2}$ but was decreased to $3.39,1.78$, and 1.22 upon treatment with $750 \mu \mathrm{M} \mathrm{H} \mathrm{H}_{2} \mathrm{O}_{2}$ after pretreatment with embelin at 2.5, 5, and $7.5 \mu \mathrm{M}$, respectively (Fig. 3c).

To confirm the effect of embelin on skin aging, expression of the COL1A1 gene, which encodes collagen type I, was determined by qRT-PCR. The results showed that the expression of the COL1A1 gene was decreased from 1 to 0.60 by $750 \mu \mathrm{M} \mathrm{H}_{2} \mathrm{O}_{2}$ but was increased to $0.75,0.81$, and 0.84 upon treatment with $750 \mu \mathrm{M} \mathrm{H}_{2} \mathrm{O}_{2}$ after $2.5,5$, and $7.5 \mu \mathrm{M}$ embelin pretreatment, respectively (Fig. 3d).

A wound-healing assay was also used to determine the effect of embelin on cell mobility. The results showed that cell mobility was decreased from 1 to 0.32 by $750 \mu \mathrm{M}$ $\mathrm{H}_{2} \mathrm{O}_{2}$, but cell mobility increased to $0.59,0.69$, and 0.98 upon treatment with $750 \mu \mathrm{M} \mathrm{H}_{2} \mathrm{O}_{2}$ after pretreatment with embelin at $2.5,5$, and $7.5 \mu \mathrm{M}$, respectively (Fig. 3e).

\section{Discussion}

\section{Antioxidant effect of embelin}

SOD, a typical antioxidant enzyme that reduces oxidative stress in humans, converts superoxide anion into hydrogen peroxide to lower the active oxygen concentration in the body (McCord and Fridovich 1969; Fridovich 1995). These SODs are classified into three types in humans: SOD1 is present in the cytoplasm, SOD2 is present in the mitochondria, and SOD3 is present outside the cell (Huang et al. 1999). Among these, SOD1 is the most important antioxidant enzyme and decreases ROS in all tissues in which oxygen, including cytoplasm, is present (Crapo et al. 1992). 
a

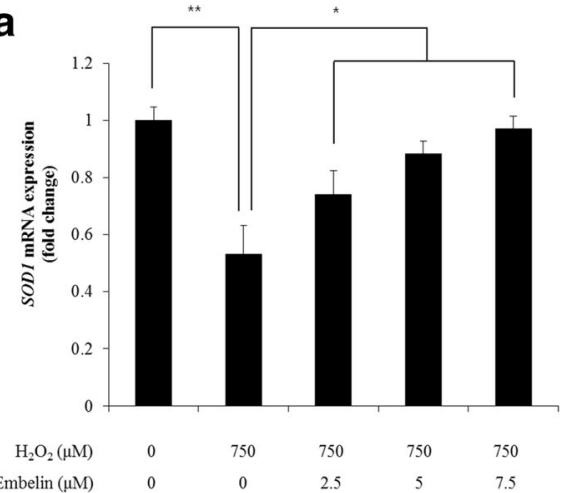

b

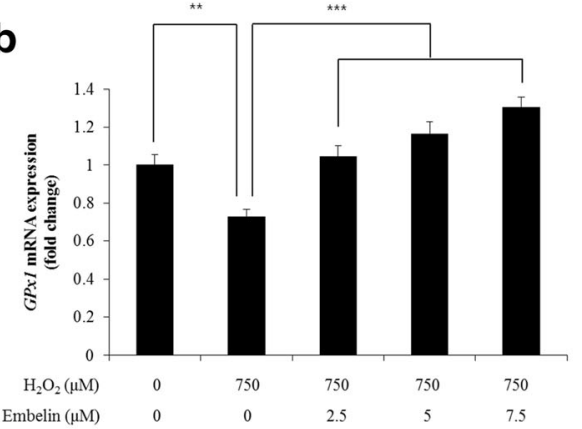

C
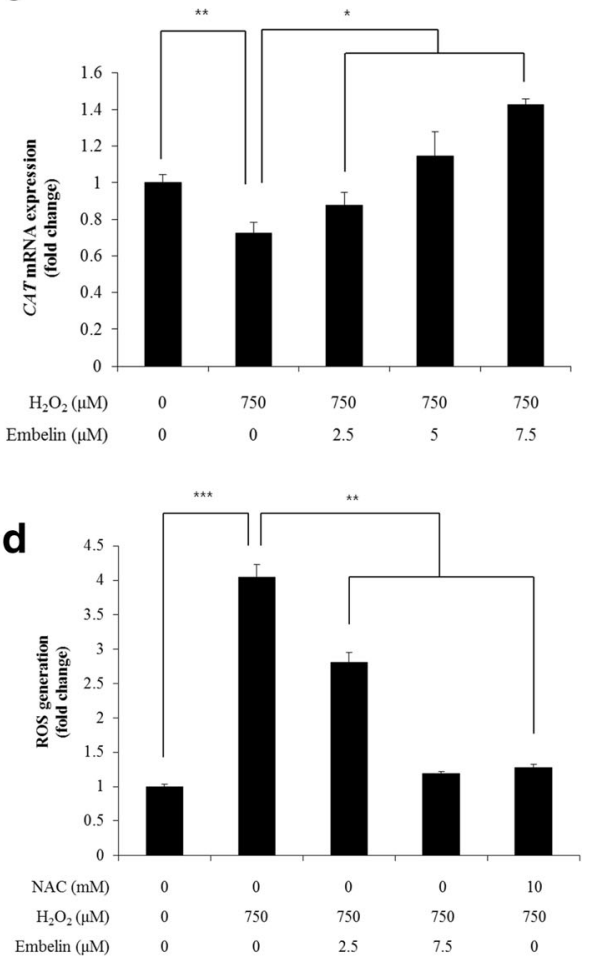

Fig. 2 Antioxidant effect of embelin. a Elevation of SOD1 gene expression by embelin treatment in $\mathrm{H}_{2} \mathrm{O}_{2}$-treated HDFs $\left({ }^{*} p<0.05\right.$, $\left.{ }^{* *} p<0.01\right)$. b Elevation of GPx1 gene expression by embelin treatment in $\mathrm{H}_{2} \mathrm{O}_{2}$-treated HDFs ( ${ }^{* *} p<0.01$, ${ }^{* * *} p<0.001$ ). c Elevation of CAT gene expression by embelin in $\mathrm{H}_{2} \mathrm{O}_{2}$-treated HDFs $\left({ }^{*} p<0.05\right.$, $\left.{ }^{* *} p<0.01\right)$. d The ROS scavenging effect of embelin in $\mathrm{H}_{2} \mathrm{O}_{2}$-treated HDFs $\left({ }^{* *} p<0.01,{ }^{* * *} p<0.001\right)$

Therefore, it is suggested that embelin induces the antioxidative effect of superoxide anion by converting it into hydrogen peroxide by increasing the expression of the SOD1 gene, a cytotoxic antioxidant enzyme, in a concentration-dependent manner.

Among the antioxidant enzymes, SOD catalyzes the conversion of superoxide into $\mathrm{O}_{2}$ and $\mathrm{H}_{2} \mathrm{O}_{2}$, and the $\mathrm{H}_{2} \mathrm{O}_{2}$ produced is decomposed into $\mathrm{H}_{2} \mathrm{O}$ and $\mathrm{O}_{2}$ by glutathione peroxidase 1 (GPx1). GPx1 is present in the cytoplasm and mitochondria and protects cells from oxidative damage (Masella et al. 2005; Orhan et al. 2005). Therefore, it is considered that embelin increases antioxidative enzyme GPx1 gene expression in a dose-dependent manner, which is more effective in decomposing $\mathrm{H}_{2} \mathrm{O}_{2}$ into $\mathrm{H}_{2} \mathrm{O}$ and $\mathrm{O}_{2}$, which are in turn safer for the body than antioxidants.

The antioxidant enzyme CAT acts as a catalyst to convert $\mathrm{H}_{2} \mathrm{O}_{2}$ produced by SOD to $\mathrm{H}_{2} \mathrm{O}$ and $\mathrm{O}_{2}$ (Brioukhanov and Netrusov 2004). Therefore, it is considered that embelin increases antioxidative enzyme $C A T$ gene expression in a dose-dependent manner and acts as a catalyst to convert $\mathrm{H}_{2} \mathrm{O}_{2}$ into noxious $\mathrm{H}_{2} \mathrm{O}$ and $\mathrm{O}_{2}$.

ROS produced by $\mathrm{H}_{2} \mathrm{O}_{2}$ damage the cellular function of normal skin and disrupt the balance of antioxidant defenses there, resulting in the loss of gloss, formation of wrinkles, and loss of elasticity (Yaar and Gilchrest 2007).
Embelin may decrease ROS that are increased by $\mathrm{H}_{2} \mathrm{O}_{2}$ in a dose-dependent manner and inhibit cellular damage of normal skin.

\section{Inhibition of senescence effect of embelin}

Aging of cells involves the in vivo loss of their regenerative ability, with no further cell division, and occurs when the DNA damage is slightly weaker than the level required to cause cell death (Campisi and d'Adda di Fagagna 2007). Senescence-associated $\beta$-galactosidase (SA- $\beta$-galactosidase) activity is a characteristic of aged cells and is widely used as an aging cell indicator (Dimri et al. 1995). In view of the obtained findings, $\mathrm{H}_{2} \mathrm{O}_{2}$ seems to induce cell senescence, and it is considered that embelin inhibits cell senescence in a concentration-dependent manner.

When DNA damage is caused by $\mathrm{H}_{2} \mathrm{O}_{2}$, p53 is activated and induces p21 gene expression. These results suggest that p21 inhibits the function of cyclin-dependent kinase (CDK), arrests the cell cycle, and inhibits cell growth (Smits and Medema 2001; Gewirtz et al. 2008). Therefore, it is considered that embelin inhibits cell senescence by activating CDK function by decreasing the expression of $p 21$, a gene that stops the cell cycle and promotes senescence in a concentration-dependent manner. 

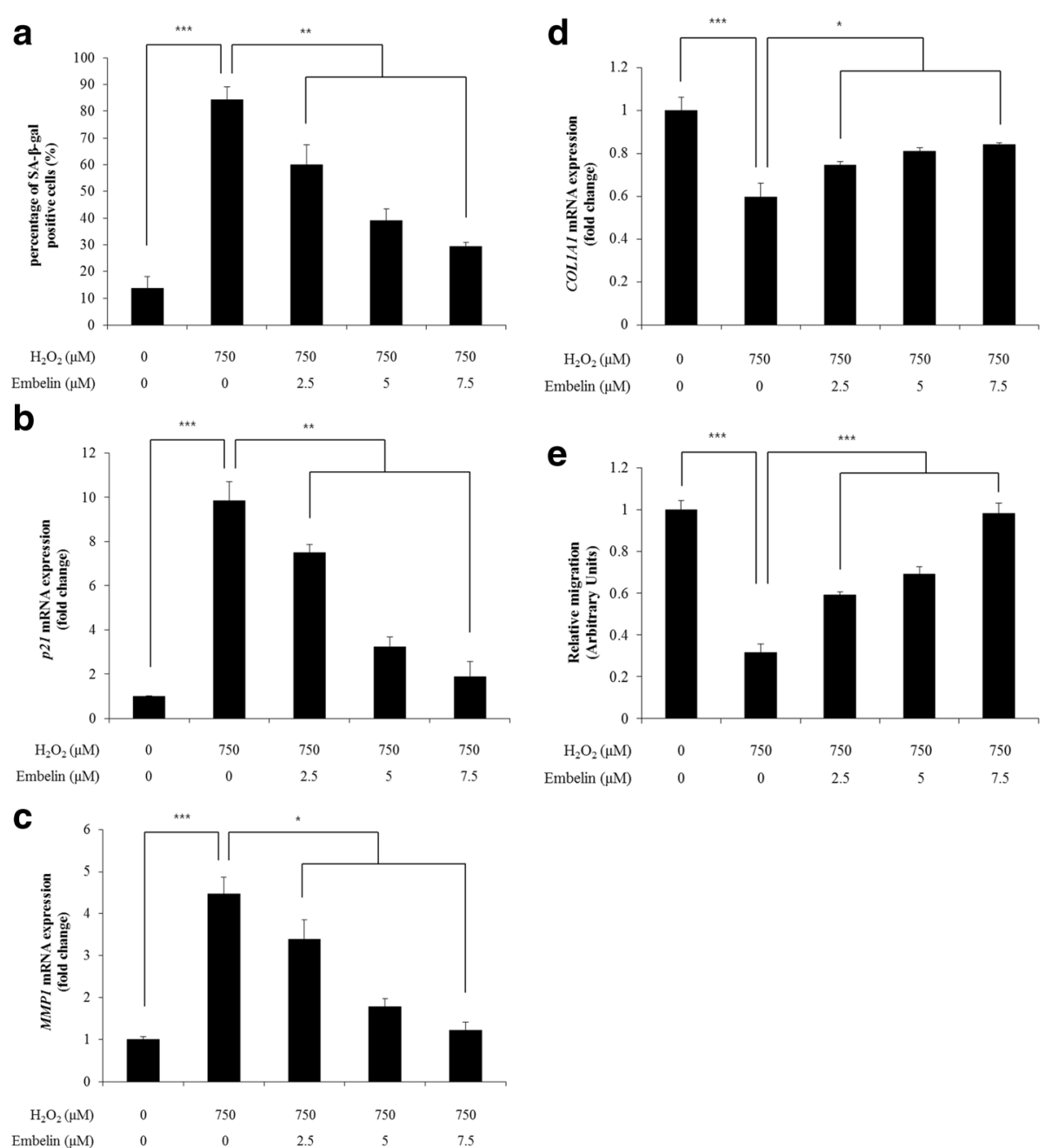

Fig. 3 Inhibition senescence effect of embelin. a Inhibiting of cellular senescence by embelin in $\mathrm{H}_{2} \mathrm{O}_{2}$-treated HDFs $\left({ }^{* *} p<0.01\right.$, $\left.{ }^{* * *} p<0.001\right)$. b Inhibition of $p 21$ gene expression by embelin in $\mathrm{H}_{2} \mathrm{O}_{2}$-treated HDFs $\left({ }^{* *} p<0.01,{ }^{* * *} p<0.001\right)$. c Inhibition of MMP1 gene expression by embelin in $\mathrm{H}_{2} \mathrm{O}_{2}$-treated $\mathrm{HDFs}$ $\left({ }^{* *} p<0.01,{ }^{* * *} p<0.001\right)$. d Elevation of COL1A1 gene expression by embelin treatment in $\mathrm{H}_{2} \mathrm{O}_{2}$-treated HDFs $\left({ }^{*} p<0.05\right.$, $\left.{ }^{* *} p<0.01\right)$. e Elevation of cell migration by embelin treatment in $\mathrm{H}_{2} \mathrm{O}_{2}$-treated HDFs ${ }^{* * *} p<0.001$ )

MMP1 is mainly produced or secreted by fibroblasts and is a representative enzyme that reduces the elasticity of the dermis and breaks down the collagen fibers; it is used as an index of skin aging with collagen fibers (Steinhoff et al. 2004; Lee et al. 2006). Therefore, it is concluded that embelin inhibits type I collagen degradation by inhibiting $M M P 1$ expression, which promotes collagen fiber degradation in a dose-dependent manner.

HDFs play a role in producing collagen, which accounts for $90 \%$ of the skin dermis. Collagen is involved in denseness of dermis, elasticity, binding force of tissue, adhesion of cells, cell proliferation, and differentiation (Perlish et al. 1988). Collagen has various types, of which $84 \%$ are type I. Type I is present in the skin, muscles, and bones (Cutroneo 2003). It is suggested that embelin increases COL1A1 expression, which leads to collagen synthesis in a dose-dependent manner, thereby activating collagen synthesis, which occupies most of the dermis.

Damaged cells express the genes typically expressed in cells such as fibroblasts to regain a normal state, accompanied by cell migration and cell proliferation. Cell proliferation and cell mobility of HDFs are essential for the retention of skin tissue and inhibition of aging (Stevenson and Thornton 2007). This study suggests that embelin activates the regeneration of cells damaged by $\mathrm{H}_{2} \mathrm{O}_{2}$ in a concentration-dependent manner and promotes cell mobility.

\section{Conclusions}

Research on the development of antiaging cosmetics has been increasing worldwide; anticancer, anti-inflammation, and antioxidant research in the fields of medicine and pharmacology for embelin has been reported, but research 
on the use of embelin as a cosmetic raw material has not been conducted, to the best of our knowledge. To confirm the possibility of using embelin as an antiaging component of cosmetics, HDF was pretreated with embelin concentration and oxidative stress was induced by $\mathrm{H}_{2} \mathrm{O}_{2}$. I confirmed the antioxidant and inhibition of senescence effect of embelin through the changes.

Here, I examined the cytotoxicity of embelin and its cytoprotective effect on $\mathrm{H}_{2} \mathrm{O}_{2}$ in HDFs. The results showed that the survival rates with embelin at $2.5,5$, and $7.5 \mu \mathrm{M}$ were 97,93 , and $86 \%$, respectively, but cell viability was reduced to $67 \%$ at a concentration of $10 \mu \mathrm{M}$. In subsequent experiments, $7.5 \mu \mathrm{M}$ was thus applied as the maximum concentration. In addition, it was confirmed that cell viability was recovered in a concentration-dependent manner upon pretreatment of human dermal fibroblasts with $750 \mu \mathrm{M} \mathrm{H} \mathrm{H}_{2} \mathrm{O}_{2}$ at embelin concentrations of $2.5,5$, and $7.5 \mu \mathrm{M}$.

I confirmed the antioxidant effect of embelin in HDFs. Specifically, quantitative analysis of ROS by DCE-DA confirmed that ROS generated by $\mathrm{H}_{2} \mathrm{O}_{2}$ in HDFs were removed by embelin, showing that the radical scavenging ability increased in a concentration-dependent manner after embelin pretreatment, as was also the case for the positive control NAC. In addition, the expression of the $S O D 1, G P x 1$, and CAT genes, which encode antioxidative enzymes, was also increased in a dose-dependent manner after embelin pretreatment.

The inhibitory effect of embelin on HDFs was also confirmed. The activity of $\beta$-galactosidase, an indicator of aging cells, was decreased by embelin in a concentrationdependent manner. In addition, it was confirmed that aging was inhibited by decreasing the expression of $p 21$, which is a gene that stops the cell cycle and promotes senescence. As the concentration of embelin increased, the expression of $M M P 1$, a typical enzyme for reducing the elasticity of collagen and of the dermis, was also decreased in a dosedependent manner. On the other hand, the expression of COL1A1, a gene that produces collagen type I, was increased in a dose-dependent manner. As a result of measuring cell mobility using a wound-healing assay, embelin is thought to stimulate cell regeneration and cell migration in a concentration-dependent manner.

The results of this study confirm that embelin restores the survival rate of HDFs damaged by $\mathrm{H}_{2} \mathrm{O}_{2}$ in a concentrationdependent manner and has antioxidant and antiaging effects. Therefore, it is considered that embelin can be used as a cosmetic material having antiaging effects on HDFs. However, further studies involving clinical trials are needed to verify the results of this work.

\section{Abbreviations}

CAT: Catalase; CDK2: Cyclin-dependent kinase 2; CDK4: Cyclin-dependent kinase 4; COL1A1: Collagen type I alpha 1 chain; DCF-DA: Dichlorofluorescein diacetate; DMEM: Dulbecco's modified Eagle's medium; DMSO: Dimethyl sulfoxide; ECM: Extracellular matrix; FBS: Fetal bovine serum; GPx1: Glutathione peroxidase 1;
HDF: Human dermal fibroblast; MMP1: Matrix metallopeptidase 1; NAC: NAcetyl-L-cysteine; NF-kB: Nuclear factor kB; p21: Cyclin-dependent kinase inhibitor 1A; PBS: Phosphate-buffered saline; qRT-PCR: Quantitative realtime polymerase chain reaction; ROS: Reactive oxygen species; SA- $\beta$ galactosidase: Senescence-associated $\beta$-galactosidase; SOD1: Superoxide dismutase 1; WST: Water-soluble tetrazolium salt

\section{Acknowledgements \\ Not applicable}

Funding

Not applicable

\section{Availability of data and materials}

Not applicable

\section{Authors' contributions}

JJ did all of the research background such as experiments, data collecting, and statistical analysis and drafted the manuscript. Both authors read and approved the final manuscript.

Ethics approval and consent to participate

Not applicable

Consent for publication

Not applicable

Competing interests

The authors declare that they have no competing interests.

\section{Publisher's Note}

Springer Nature remains neutral with regard to jurisdictional claims in published maps and institutional affiliations.

\section{Author details}

${ }^{1}$ Suwon Women's University, Suwon-si, Gyeongi-do, Republic of Korea. ${ }^{2}$ Beauty People Beauty School, 68, Dolma-ro, Bundang-gu, Seongnam-si, Gyeonggi-do, Republic of Korea.

Received: 21 September 2017 Accepted: 7 February 2018

Published online: 15 March 2018

\section{References}

Braverman IM, Fonferko E. Studies in cutaneous aging: I. The elastic fiber network J Invest Dermatol. 1982:78:434-43.

Brioukhanov AL, Netrusov Al. Catalase and superoxide dismutase: distribution, properties, and physiological role in cells of strict anaerobes. Biochemistry. 2004;69:949-62.

Campisi J. The role of cellular senescence in skin aging. J Investig Dermatol Symp Proc. 1998:3:1-5.

Campisi J, d'Adda di Fagagna F. Cellular senescence: when bad things happen to good cells. Nat Rev Mol Cell Biol. 2007;8:729-40.

Crapo JD, Qury T, Rabouille C, Slot JW, Chang LY. Copper, zinc superoxide dismutase is primarily a cytosolic protein in human cells. Proc Natl Acad Sci. 1992:89:10405-9.

Cutroneo KR. How is type I procollagen synthesis regulated at the gene level during tissue fibrosis. J Cell Biochem. 2003;90:1-5.

Dhadde SB, Nagakannan P, Roopesh M, Anand Kumar SR, Thippeswamy BS, Veerapur VP, et al. Effect of embelin against 3-nitropropionic acid-induced Huntington's disease in rats. Biomed Pharmacother. 2016;77:52-8.

Dharmapatni AA, Cantley MD, Marino V, Perilli E, Crotti TN, Smith MD, et al. The $X$-linked inhibitor of apoptosis protein inhibitor embelin suppresses inflammation and bone erosion in collagen antibody induced arthritis mice. Mediat Inflamm. 2015;2015:10.

Dimri GP, Lee X, Basile G, Acosta M, Scott G, Roskelley C, et al. A biomarker that identifies senescent human cells in culture and in aging skin in vivo. Proc Natl Acad Sci. 1995;92:9363-7.

El-Domyati M, Attia S, Saleh F, Brown D, Birk DE, Gasparro F, et al. Intrinsic aging vs. photoaging: a comparative histopathological, immunohistochemical, and ultrastructural study of skin. Exp Dermatol. 2002;11:398-405. 
Fridovich I. Superoxide radical and superoxide dismutase. Annu Rev Biochem. 1995;64:97-112.

Gewirtz DA, Holt SE, Elmore LW. Accelerated senescence: an emerging role in tumor cell response to chemotherapy and radiation. Biochem Pharmacol. 2008;76:947-57

Heck DE, Vetrano AM, Mariano TM, Laskin JD. UVB light stimulates production of reactive oxygen species: unexpected role for catalase. J Biol Chem. 2003;278:22432-6.

Huang TT, Carlson EJ, Raineri I, Grillespie AM, Kozy H, Epstein CJ. The use of transgenic and mutant mice to study oxygen free radical metabolism. Ann N Y Acad Sci. 1999;893:95-112.

Kang S, Cho S, Chung JH, Hammerberg C, Fisher GJ, Voorhees JJ. Inflammation and extracellular matrix degradation mediated by activated transcription factors nuclear factor-kappaB and activator protein-1 in inflammatory acne lesions in vivo. Am J Pathol. 2005;166:1691-9.

Karlsson M, Kurz T, Brunk UT, Nilsson SE, Frennesson Cl. What does the commonly used DCF test for oxidative stress really show? Biochem J. 2010; 428:183-90.

Lee J, Jung E, Lee J, Huh S, Hwang CH, Lee HY, et al. Emodin inhibits TNF alphainduced MMP-1 expression through suppression of activator protein-1(AP-1). Life Sci. 2006;79:2480-5.

Lee YR, Noh EM, Han JH, Kim JM, Hwang BM, Cung EY, et al. Brazilin inhibits UVB-induced MMP-1/3 expressions and secretions by suppressing the NF-KB pathway in human dermal fibroblast. Eur J Pharmacol. 2012;674:80-6.

Li Y, Li D, Yuan S, Wang Z, Tang F, Nie R, et al. Embelin-induced MCF-7 breast cancer cell apoptosis and blockade of MCF-7 cells in the G2/M phase via the mitochondrial pathway. Oncol Lett. 2013;5:1005-9.

Masella R, Di Benedetto R, Vari R, Filesi C, Giovannini C. Novel mechanisms of natural antioxidant compounds in biological system: involvement of glutathione and glutathione-related enzymes. J Nutr Biochem. 2005;16: 577-86.

Matsumura Y, Ananthaswamy HN. Toxic effects of ultraviolet radiation on the skin. Toxicol Appl Pharmacol. 2004;195:298-308.

McCord JM, Fridovich I. The utility of superoxide dismutase in studying free radical reactions. I. Radicals generated by the interaction of sulfite, dimethyl sulfoxide and oxygen. J Biol Chem. 1969:244:6056-63.

Miliani de Marval PL, Zhang Y. The RP-Mdm2-p53 pathway and tumorigenesis. Oncotarget. 2011;2:234-8.

Mori T, Doi R, Kida A, Nagai K, Kami K, Ito D, et al. Effect of the XIAP inhibitor embelin on TRAlL-induced apoptosis of pancreatic cancer cells. J Surg Res. 2007;142:281-6.

Naik SR, Niture NT, Ansari AA, Shah PD. Anti-diabetic activity of embelin: involvement of cellular inflammatory mediators, oxidative stress and other biomarkers. Phytomedicine. 2013;20:797-804.

Orhan $\mathrm{H}$, Evelo $\mathrm{CT}$, Sahin G. Erythrocyte antioxidant defense response against cigarette smoking in humans-the glutathione S-transferase vulnerability. J Biochem Mol Toxicol. 2005;19:226-33.

Perlish JS, Lemlich G, Fleischmajer R. Identification of collagen fibrils in scleroderma skin. J Invest Dermatol. 1988;90:48-54.

Philips N, Auler S, Hugo R, Gonzalez S. Beneficial regulation of matrix metalloproteinsases for skin health. Enzyme Res. 2011:2011:427258.

Radhakrishana N, Gnanamani A. 2, 5-Dihydroxy-3-undecyl-1, 4-benzoquinone (embelin)-a second solid gold of India - a review. Int J Pharm Pharm Sci. 2014;6:23-30

Singh D, Singh R, Singh P, Gupta RS. Effects of embelin on lipid peroxidation and free radical scavenging activity against liver damage in rats. Basic Clin Pharmacol Toxicol. 2009;105:243-8.

Smits VA, Medema RH. Checking out the G(2)/M transition. Biochim Biophys Acta. 2001:1519:1-12

Stein GH, Dulic V. Origins of G1 arrest in senescent human fibroblasts. BioEssays. 1995;17:537-43.

Steinhoff M, Griffiths CEM, Church MK, Luger TA. Inflammation, In Rook's Textbook of Dermatology. 7th ed. Oxford : Blackwell Scientic; 2004

Stevenson S, Thornton J. Effect of estrogens on skin aging and the potential role of SERMs. Clin Interv Aging. 2007;2:283-97.

Thannickal VJ, Fanburg BL. Reactive oxygen species in cell signaling. Am J Phys Lung Cell Mol Phys. 2000;279:1005-28

Uitto J. Connective tissue alterations in collagen and elastin. Dermatol Clin. 1986; 4:433-46.

Urso ML, Clarkson PM. Oxidative stress, exercise, and antioxidant supplementation. Toxicology. 2003;189:41-54
Varani J, Perone P, Fligiel SE, Fisher GJ, Voorhees JJ. Inhibition of type I procollagen production in photodamage: correlation between presence of high molecular weight collagen fragments and reduced procollagen synthesis. J Invest Dermatol. 2002;119:122-9.

Yaar M, Gilchrest BA. Photoaging: mechanism, prevention and therapy. Br J Dermatol. 2007;157:874-87.

Yoon YM, Bae SH, An SK, Choe YB, Ahn KJ, An IS. Effects of ultraviolet radiation on the skin and skin cell signaling pathways. Kor J Aesthet Cosmetol. 2013; 11:417-26.

\section{Submit your next manuscript to BioMed Central and we will help you at every step:}

- We accept pre-submission inquiries

- Our selector tool helps you to find the most relevant journal

- We provide round the clock customer support

- Convenient online submission

- Thorough peer review

- Inclusion in PubMed and all major indexing services

- Maximum visibility for your research

Submit your manuscript at www.biomedcentral.com/submit

) Biomed Central 